\title{
SERBEST ECZACILARIN ZAMAN YÖNETIMI TIME MANAGEMENT ON COMMUNITY PHARMACISTS
}

\section{Ceyda ÖNCEL ${ }^{1}$ Şener BÜYÜKÖZTÜRK ${ }^{2}$ Gülbin ÖZÇELIKAY ${ }^{1}$}

${ }^{1}$ Ankara Üniversitesi, Eczacılık Fakültesi, Eczacılık İşletmeciliği Anabilim Dalı, 06100 TandoğanAnkara, TÜRKIYE

${ }^{2}$ Başkent Üniversitesi, Eğitim Fakültesi, Ankara, TÜRKIYE

\section{ÖZET}

“Zaman Yönetimi” denildiğinde, kişinin zamanın akışı içinde kendisini yönetmesi anlaşılmalıdır.

Eczacılıkta zaman, etkin ve verimli bir şekilde kullanılırsa, eczacının verimliliği ve de dolayısıyla hastaya sunulan hizmetin kalitesi artacaktır.

Bu çalışmanın amacl, önemli bir hizmetin yerine getirilmesinde rol alan serbest eczacıların iyi bir zaman yöneticisi olup olmadıklarını, ne tür zaman tuzaklarına yakalandıklarını, bu zaman tuzaklarından kurtulma çarelerinin neler olduğunu ve zamanı etkin ve verimli kullanamama sonucu karşılaştıkları aksaklıkların neler olduğunu belirlemektir. Çalışmanın materyalini Ankara ilinde bulunan 213 eczane eczacısına yüz yüze uygulanan anket formları oluşturmaktadır. Araştırmada verilerin değerlendirilmesinde SPSS (ver. 10.0) istatistiksel paket programı kullanılmıştır.

Çalışma sonuçlarına göre eczacıların planlama boyutuyla ilgili olarak zaman yönetimi davranışları arasında cinsiyete göre anlamlı fark bulunmuştur, t(211)=2.23, p<.05. Erkek eczacıların $(\bar{X}=50.82)$, kadınlara $(\bar{X}=47.47)$ göre zamanlarını daha etkili kullandıkları anlaşılmaktadır.

Eczacıların uygulama boyutuna ilişkin zaman yönetimi davranışları arasında cinsiyete göre anlamlı fark bulunmamıştır, $t(211)=1.26, p>.05$.

Anahtar Kelimeler: Zaman, Eczacı, Zaman Yönetimi, Serbest Eczane, Serbest Eczacı

\section{ABSTRACT}

“Time Management” connotes that a person's self management the course of time. 
When the time is used effectively and productively in pharmacy, pharmacist's productivity and so quality of the service for the patient will improve.

The purpose of this study is to determine whether the pharmacists who take part in carrying out an important service are good time managers or not, what kind of time traps the pharmacists get caught, what are the solutions to escape from these time traps and what are the troubles because of not managing the time in an effective and productive way.

The materials of this study are the questionnaire formst filled face to face with 213 pharmacists who have community pharmacies in Ankara.

Research data is analyzed with statistical package program SPSS (version 10.0).

According to the results of this study; there are significant differences about planning side of time management relative to gender, $t(211)=2,23, p<., 05$. It is understood that male pharmacists $(X=50.82)$ are using their time more effectively than female pharmacists $(X=4 ., 47)$. Among the behaviors of the application side of time management, no significant differences were found relative to gender.

Key words: Time, Pharmacist, Time Management, Community Pharmacy, Community Pharmacist

\section{GİRIŞ̧}

Rekabetin hızla arttığı ve birim zamanda özümsenmesi gereken bilgi sayısının eskiye nazaran giderek çoğaldığı günümüzde, insanların zamana karşı duyarlılığı da farklılaşmaktadır. Çağdaş işletmeciler zamanı, kıt kaynaklar arasında ve geri dönüşü mümkün olmayan, toplanamayan, ertelenemeyen, biriktirilemeyen, bu nedenle de dikkatli kullanılması gereken bir faktör olarak değerlendirmektedirler (1).

Zaman, Türk Dil Kurumu Sözlüğü' nde "Bir iş ya da oluşun içinden geçtiği, geçeceği veya geçmekte olduğu süre", olarak tanımlanmaktadır (2).

Zaman hepimizin eşit olarak sahip olduğu, her meslekten bireyler üzerinde baskı yapan evrensel bir kaynaktır. Profesyonel çalışma yapan herkes zamanını akıllıca kullanmak ve planlamak zorundadır.

Böylesine değerli bir kaynak olan zamanın etkili ve üretken olarak kullanılabilmesi son yıllarda “ Zaman Yönetimi” adlı yeni bir kavramın ortaya çıkmasına neden olmuştur. Drucker’ın dediği gibi "Zaman eşi az bulunan kaynaktır. Eğer o doğru yönetilmiyorsa hiçbir şey doğru yönetiliyor sayılamaz" (3). 
Zaman yönetimi denildiğinde, kişinin zamanın akışı içinde kendisini yönetmesi anlaşılmalıdır (4).

Eczacılık; eczane, ecza deposu, ecza dolabı, galenik, tıbbi ve ispençiyari mevad ve müstahzarat labaratuarı veya imalathanesi ihzar veya imal etmek ya da resmi veya özel müesseselerde mesul müdürlük yapmaktır (5).

Her meslek dalında olduğu gibi, eczacılıkta da zaman yönetimi büyük önem taşır. İnsan sağlığı gibi çok önemli bir sektörde hizmet vermekte olan eczacıların hem çalışma saatleri fazladır, hem de çalışma tempoları çok yoğundur. Bu nedenle de zamanı son derece etkin ve verimli kullanmak zorundadırlar.

$\mathrm{Bu}$ çalışmanın amacı, böyle önemli bir hizmetin yerine getirilmesinde rol alan serbest eczacıların iyi bir zaman yöneticisi olup olmadıklarını, ne tür zaman tuzaklarına yakalandıklarını, bu zaman tuzaklarından kurtulma çarelerinin neler olduğunu, örnekleme alınan 213 eczacının zamanı etkin ve verimli kullanamama sonucu karşılaştıkları aksaklıkların neler olduğunu belirlemektir.

\section{MATERYAL VE YÖNTEM}

Bu çalışmada Ankara'da bulunan 1346 serbest eczane eczacısından evrendeki birey sayısı biliniyorsa uygulanan formül kullanılarak hesaplanan örnekleme sayısı olan 213 eczane eczacısına, yüz yüze yöntemle anket uygulanmıştır (6).

Araştırmanın materyalini, 213 eczacıya uygulanan anket formları oluşturmaktadır.

Anketteki soruların ön uygulama ile anlaşılabilirliği denenmiştir. Anket sırasında tek tip anket formu kullanılmıştır. Anket formu 213 serbest eczanenin eczacılarına uygulanmış ve 213 adet anket formu geri dönmüştür.

\section{Verilerin Analizi}

Anket ile toplanan verilerin analizi için SPSS (10.0) istatistik programı kullanılmıştır. Araştırmaya katılan eczacıların zaman yönetimi davranışlarını betimlemek amacıyla aritmetik ortalama kullanılmıştır. Katılımcıların zaman yönetimi davranışları arasında cinsiyete göre anlamlı fark olup olmadığı t-testi ile, yaşa ve eczacılık süresine göre fark olup olmadığı ise Varyans Analizi ile test edilmiştir. Varyans Analizi sonuçları anlamlı çıkması durumunda farkın hangi ikili gruplar arasında olduğunu belirlemek amacıyla Scheffe Çoklu Karşılaştırma testi uygulanmıştır. 


\section{BULGULAR}

\section{Eczacıların Zaman Yönetimi Davranışları Anketinin Geçerlik ve Güvenilirliği}

Eczacıların zamanlarını etkili bir şekilde yönetip yönetmediklerini saptamak amacıyla oluşturulan “Zaman Yönetimi Davranışları Anketi”nin (ZYDA) geçerlik ve güvenilirlik çalışmaları aşağıda kısaca açıklanmıştır.

Anketin geliştirilmesinde ilk aşamada, ankette yer alacak sorular için bir madde havuzu oluşturulmuştur. Bunun için, ilgili literatür taranmış, eczacılar ve meslektaşlarla konu hakkında görüşmeler yapılmıştır. Madde havuzunda yer alan sorular tekrar incelenerek düzeltmeler yapılmış ve 31 maddelik deneme formuna ulaşılmıştır. Ankette yer alan sorular için, beş dereceli cetvel kullanılmıştır. Cevap seçenekleri şunlardır: "Hiç", "ara sıra”, "oldukça sık”, "çok sık” ve "her zaman" Sorulardan 21'i olumlu 10’u olumsuz ifadelerden oluşmaktadır. Cevaplar, olumlu ifadelerde 1'den 5'e, olumsuz ifadelerde 5'ten 1'e doğru puanlanmıştır. Buna göre yüksek puan, bireyin zamanı etkili kullandığını göstermektedir.

Anketin faktör yapısını, yapı geçerliliğini, incelemek için Varimax Dik Döndürme kullanılarak, Temel Bileşenler Analizi kullanılmıştır. Yapılan ilk analiz sonuçları, altı madde faktörüyle düşük yük değeri göstermesi nedeniyle, anketten çıkartılarak analiz tekrar edilmiş ve analiz sonuçları anketin zaman yönetimi davranışlarını iki faktörde topladığı görülmüştür (Tablo 1). Anketin 17 maddeden oluşan birinci faktörü "planlama", 8 maddeden oluşan faktörü ise, "uygulama" olarak tanımlanmıştır.

Tablo 1. ZYDA'nin Faktör Analizi Sonuçları

\begin{tabular}{|l|c|c|c|}
\hline & \multirow{2}{*}{$\begin{array}{c}\text { Ortak Varyans } \\
\text { Madde }\end{array}$} & \multicolumn{2}{|c|}{ Faktör Yük Değeri } \\
\cline { 2 - 4 } (comunality) & Faktör 1 & Faktör 2 \\
\hline FAKTÖR 1: Planlama & & & .01 \\
\hline $\begin{array}{l}\text { 1.Zamanınızı kimlere ve nereye harcadı̆̆ınızın } \\
\text { analizini yapar mısınız? }\end{array}$ & .44 & .66 & .29 \\
\hline $\begin{array}{l}\text { 2.İşinizle ilgili bir yıllık veya daha uzun süreli } \\
\text { amaçlar belirler misiniz? }\end{array}$ & .51 & .65 & .13 \\
\hline $\begin{array}{l}\text { 3.Günlük veya haftalık yaptığınız programları } \\
\text { değerlendirir misiniz? }\end{array}$ & .42 & .64 & .33 \\
\hline $\begin{array}{l}\text { 4.Beklenmedik ve acil durumlar için ek zaman } \\
\text { ayırır mısınız? }\end{array}$ & .49 & .62 & .36 \\
\hline $\begin{array}{l}\text { 5.Bir işe başladıktan sonra işi bitirene kadar 1srar } \\
\text { eder misiniz? }\end{array}$ & .48 & .59 & .19 \\
\hline $\begin{array}{l}\text { 6.İşinizin kesilmesini önlemek için önlemler alıyor } \\
\text { musunuz? }\end{array}$ & .38 & .59 & \\
\hline
\end{tabular}




\begin{tabular}{|c|c|c|c|}
\hline $\begin{array}{l}\text { 7.İ̇slerinize yararı olmayacak görüşmeleri } \\
\text { reddedebiliyor musunuz? }\end{array}$ & .31 & .56 & .04 \\
\hline 8.Yapılan işlerde mükemmellik arar mısınız? & .35 & .54 & .25 \\
\hline $\begin{array}{l}\text { 9.Beklemediğiniz ziyaretçiler için belirli kabul } \\
\text { saatleri ayarlıyor musunuz? }\end{array}$ & .39 & .54 & .32 \\
\hline $\begin{array}{l}\text { 10.Yapılacak işleriniz için son bitim tarihi belirler } \\
\text { misiniz? }\end{array}$ & .31 & .53 & .19 \\
\hline $\begin{array}{l}\text { 11.Yapmanız gereken işleri önemli olmayan } \\
\text { nedenlerle erteler misiniz? }\end{array}$ & .30 & .52 & .17 \\
\hline $\begin{array}{l}\text { 12.Bir gün sonrası için veya herhangi bir zaman } \\
\text { dilimi içerisinde yapacaklarınızın listesini hazırlar } \\
\text { mısınız? }\end{array}$ & .26 & .51 & .01 \\
\hline $\begin{array}{l}\text { 13.Eczanede çalışan personelinizin size sorunlarını } \\
\text { anlatabilmeleri için günün veya haftanın belirli bir } \\
\text { bölümünü ayırıyor musunuz? }\end{array}$ & .25 & .50 & .03 \\
\hline $\begin{array}{l}\text { 14.Günlük işlerinizi belirli bir programa göre yapar } \\
\text { mısınız? }\end{array}$ & .23 & .48 & .06 \\
\hline $\begin{array}{l}\text { 15.Yapılacak işleri öncelik ve önem sırasına göre } \\
\text { dizer misiniz? }\end{array}$ & .21 & .45 & .05 \\
\hline 16.İşlerinizi planlamak için zaman ayırır mısınız? & .15 & .38 & .10 \\
\hline $\begin{array}{l}\text { 17.İ̧slerinizi son anda yetiştirme durumunu yaşıyor } \\
\text { musunuz? }\end{array}$ & .15 & .38 & .01 \\
\hline \multicolumn{4}{|l|}{ FAKTÖR 2: Uygulama } \\
\hline $\begin{array}{l}\text { 18.Randevu ve görüşme saatlerine uyuyor } \\
\text { musunuz? }\end{array}$ & .48 & .15 & .67 \\
\hline $\begin{array}{l}\text { 19.Herşeyin yerli yerinde olduğu ve kolayca } \\
\text { bulunabileceği bir dosyalama sistemine önem verir } \\
\text { misiniz? }\end{array}$ & .39 & .10 & .62 \\
\hline 20.Eve iş götürür müsünüz? & .42 & .24 & .60 \\
\hline $\begin{array}{l}\text { 21.Eczanenizle ilgili evrak ve faturaları zamanında } \\
\text { kontrol edip düzenliyor musunuz? }\end{array}$ & .22 & .14 & .45 \\
\hline $\begin{array}{l}\text { 22. Bir işten diğerine plansız ve amaçsız bir } \\
\text { biçimde geçme eğiliminde misiniz? }\end{array}$ & .37 & .43 & .44 \\
\hline $\begin{array}{l}\text { 23.Özel ricalarla veya kendi isteğinizle başkalarının } \\
\text { işlerini yapar mısınız? }\end{array}$ & .19 & .02 & .44 \\
\hline 24.Özel telefon görüşmeleri yapar mısınız? & .28 & .29 & .44 \\
\hline $\begin{array}{l}\text { 25.Masanızın üzerinde halen çalıştığınız konu ile } \\
\text { ilgisi olmayan şeyler bulunur mu? }\end{array}$ & .33 & .40 & .41 \\
\hline
\end{tabular}


Tablo 1 incelendiğinde iki faktörün bir maddede açıkladıkları ortak varyans miktarı, .15 ile .51 arasında değişmektedir. Maddelerin faktörle ilişkisini veren yük değerleri ise, birinci faktör için .38 - .68, ikinci faktör için .41 - .67 arasında değişmektedir. Bu bulgular, ZYDA'nin iki faktörden oluşan bir yapıya sahip olduğunu göstermektedir. Birinci faktörün açıkladığ 1 varyans \%22.2, ikinci faktörün açıkladığı varyans \%11.1 olup, toplam açıklanan varyans \%33.3'dür.

ZYDA'de yer alan soruların geçerliliği düzeltilmiş madde-toplam korelasyonları ile incelenmiştir. Analiz sonuçları Tablo 2'de gösterilmiştir.

Tablo 2: ZYDA’nin Madde Analizi Sonuçları

\begin{tabular}{|c|c|c|c|}
\hline Madde & $\begin{array}{l}\text { Düzeltilmiş } \\
\text { Madde-Toplam } \\
\text { Korelasyonu }\end{array}$ & Madde & $\begin{array}{l}\text { Düzeltilmiş } \\
\text { Madde-Toplam } \\
\text { Korelasyonu }\end{array}$ \\
\hline Faktör 1 & & Faktör 2 & \\
\hline 1 & .58 & 18 & .46 \\
\hline 2 & .57 & 19 & .34 \\
\hline 3 & .55 & 20 & .44 \\
\hline 4 & .56 & 21 & .24 \\
\hline 5 & .49 & 22 & .38 \\
\hline 6 & .53 & 23 & .27 \\
\hline 7 & .45 & 24 & .30 \\
\hline 8 & .45 & 25 & .38 \\
\hline 9 & .47 & & \\
\hline 10 & .46 & & \\
\hline 11 & .43 & & \\
\hline 12 & .45 & & \\
\hline 13 & .43 & & \\
\hline 14 & .43 & & \\
\hline 15 & .40 & & \\
\hline 16 & .33 & & \\
\hline 17 & .28 & & \\
\hline
\end{tabular}

Tablo 2 incelendiğinde madde-faktör korelasyonlarının .24 ile .58 arasında değiştiği görülmektedir. Üç maddenin dışındaki maddelerin tamamı için aynı değer .30'un üzerindedir. Bu bulgu, zaman yönetimi davranışları bakımından maddelerin bireyleri ayırt ettiğini göstermektedir. Anketin güvenirliği için hesaplanan Cronbach alpha iç tutarlılık katsayısı birinci faktör için .85 , ikinci faktör için .66 ve toplam için .82'dir. Bu değerler, aracın güvenilir olduğunu göstermektedir. 


\section{ZYDA nin başka değişkenler açısından karşılaştırılması}

Araştırmaya katılan eczacıların ZYDA puanlarının cinsiyete göre t-testi sonuçları Tablo 3'te verilmiştir.

Tablo 3 . ZYDA Cinsiyete Göre t-Testi Sonuçları

\begin{tabular}{|c|c|c|c|c|c|c|c|}
\hline ZYDA & Cinsiyet & $\mathrm{N}$ & $\bar{X}$ & S & sd & $\mathrm{t}$ & $\mathrm{p}$ \\
\hline \multirow[t]{2}{*}{ Faktör1 } & Kadın & 135 & 47.47 & 11.30 & 211 & $2.23 *$ & .027 \\
\hline & Erkek & 78 & 50.82 & 9.14 & & & \\
\hline \multirow[t]{2}{*}{ Faktör2 } & Kadın & 135 & 30.04 & 4.61 & 211 & 1.26 & .208 \\
\hline & Erkek & 78 & 30.83 & 3.99 & & & \\
\hline \multirow[t]{2}{*}{ Toplam } & Kadın & 135 & 77.51 & 12.88 & 211 & $2.46^{*}$ & .015 \\
\hline & Erkek & 78 & 81.65 & 9.77 & & & \\
\hline
\end{tabular}

Eczacıların planlama boyutuyla ilgili olarak zaman yönetimi davranışları arasında cinsiyete göre anlamlı fark bulunmuştur, $\mathrm{t}(211)=2.23, \mathrm{p}<.05$. Erkek eczacıların $(\bar{X}=50.82)$, kadınlara $(\bar{X}=47.47)$ göre zamanlarını daha etkili kullandıkları anlaşılmaktadır.

Eczacıların uygulama boyutuna ilişkin zaman yönetimi davranışları arasında cinsiyete göre anlamlı fark bulunmamıştır, $\mathrm{t}(211)=1.26, \mathrm{p}>.05$.

Katılımcıların zaman yönetimi davranışları genel olarak incelendiğinde ise bu davranışların cinsiyete göre anlamlı farkl1lık gösterdiği, $\mathrm{t}(211)=2.46, \mathrm{p}<.05$ ve erkeklerin $(\bar{X}=81.65)$, kadınlara $(\bar{X}=77.51)$ göre zamanlarını daha iyi yönettikleri bulunmuştur.

Araştırmaya katılan eczacıların ZYDA puanlarının yaşa göre varyans analizi sonuçları Tablo 4'te, eczacılık yapma süresine göre varyans analizi sonuçları ise Tablo 5'te verilmiştir.

Tablo 4 . ZYDA Yaşa Göre Varyans Analizi Sonuçları

\begin{tabular}{|c|c|c|c|c|c|c|c|c|}
\hline ZYDA & Yaş & $\mathrm{N}$ & $X$ & $\mathrm{~S}$ & $\mathrm{sd}$ & $\mathrm{F}$ & $\mathrm{p}$ & $\begin{array}{c}\text { Gruplararas1 } \\
\text { Anlamlı Farklar }\end{array}$ \\
\hline \multirow[t]{3}{*}{ Faktör 1} & $25-34$ & 78 & 45.76 & 11.01 & 2,210 & $6.35^{*}$ & .002 & $1-3$ \\
\hline & $35-44$ & 76 & 49.07 & 9.23 & & & & \\
\hline & 45ve üzeri & 59 & 52.12 & 10.98 & & & & \\
\hline \multirow[t]{3}{*}{ Faktör 2} & $25-34$ & 78 & 30.12 & 4.00 & 2,210 & .20 & .819 & - \\
\hline & $35-44$ & 76 & 30.56 & 4.93 & & & & \\
\hline & 45ve üzeri & 59 & 30.32 & 4.24 & & & & \\
\hline \multirow[t]{3}{*}{ Toplam } & $25-34$ & 78 & 75.87 & 12.00 & 2,210 & $5.42 *$ & .005 & $1-3$ \\
\hline & $35-44$ & 76 & 79.63 & 10.49 & & & & \\
\hline & 45ve üzeri & 59 & 82.44 & 12.84 & & & & \\
\hline
\end{tabular}


Tablo 4 incelendiğinde, eczacıların planlama boyutuna ilişkin zaman yönetimi davranışları arasında yaş gruplarına göre anlamlı fark bulunmuştur, $\mathrm{F}(2,210)=6.35, \mathrm{p}<.05$. Faktör ortalama puanı 25-34 yaş grubu için 45.76, 35-44 yaş grubu için 49.07 ve 45 ve üzeri yaş grubu için 52.12 'dir. Grup ortalama puanları arasında yapılan Scheffe Testi sonuçları, üçüncü grup ile birinci grup arasında anlamlı fark olduğunu, üçüncü grubun zamanı birinci gruba göre anlamlı bir şekilde daha etkili kullandığını göstermektedir.

Eczacıların ikinci boyutla ilgili olarak zaman yönetimi davranışları arasında yaşa göre anlamlı fark bulunmamıştır, $\mathrm{F}(2,210)=.81, \mathrm{p}>.05$.

Araştırmaya katılan eczacıların zaman yönetimi davranışları arasında yaşa göre toplamda da anlamlı farkl11ık gösterdiği bulunmuştur, $\mathrm{F}(2,210)=5.42, \mathrm{p}<.05$. Gruplar arasında yapılan çoklu karşılaştırmada, 45 ve daha üzeri yaşa sahip olanların( $(\bar{X}=82.44), \quad 25-34$ yaşta olanlara ( $\bar{X}=75.87)$ göre zamanlarını genel olarak etkili kullandıkları görülmüştür.

Tablo 5 . ZYDA Eczacılık Süresine Göre Varyans Analizi Sonuçları

\begin{tabular}{|c|c|c|c|c|c|c|c|c|}
\hline ZYDA & Süre & $\mathrm{N}$ & $\bar{X}$ & $\mathrm{~S}$ & sd & $\mathrm{F}$ & $\mathrm{p}$ & $\begin{array}{l}\text { Gruplararas1 } \\
\text { Anlamlı Farklar }\end{array}$ \\
\hline \multirow[t]{5}{*}{ Faktör 1} & $1-5$ y1l & 63 & 45.43 & 11.29 & 4, 208 & $5.40 *$ & 0.003 & $1-5,3-5$ \\
\hline & 6-10 y1l & 48 & 50.19 & 7.77 & & & & \\
\hline & $11-15 \mathrm{y} 1 \mathrm{l}$ & 35 & 46.37 & 9.55 & & & & \\
\hline & $16-20$ y1l & 30 & 48.60 & 10.51 & & & & \\
\hline & 21ve üzeri & 37 & 54.62 & 11.47 & & & & \\
\hline \multirow[t]{5}{*}{ Faktör 2} & $1-5 \mathrm{y} 11$ & 63 & 30.26 & 4.15 & 4,208 & 1.23 & 0.290 & - \\
\hline & 6-10 y1l & 48 & 31.27 & 3.11 & & & & \\
\hline & $11-15 \mathrm{y} 1 \mathrm{l}$ & 35 & 29.86 & 5.95 & & & & \\
\hline & $16-20 \mathrm{y} 1 \mathrm{l}$ & 30 & 29.17 & 4.66 & & & & \\
\hline & 21ve üzeri & 37 & 30.65 & 4.27 & & & & \\
\hline \multirow[t]{5}{*}{ Toplam } & $1-5 \mathrm{y} 1 \mathrm{l}$ & 63 & 75.68 & 12.43 & 4,208 & $5.17^{*}$ & 0.012 & $1-5$ \\
\hline & 6-10 y1l & 48 & 81.46 & 8.49 & & & & \\
\hline & $11-15$ y1l & 35 & 76.23 & 10.90 & & & & \\
\hline & $16-20 \mathrm{y} 11$ & 30 & 77.77 & 11.90 & & & & \\
\hline & 21ve üzeri & 37 & 85.27 & 13.48 & & & & \\
\hline
\end{tabular}

Tablo 5 incelendiğinde, araştırmaya katılanların planlama boyutuyla ilgili olarak zaman yönetimi davranışlarının eczacılık yapma sürelerine göre anlamlı bir şekilde farklılaştığı görülmektedir, $\mathrm{F}(4,208)=5.40, \mathrm{p}<.05$. Gruplar arasında yapılan çoklu karşılaştırmalar, 21 yıl ve 
daha fazla eczacilık yapanların $(\bar{X}=54.62), \quad 1-5$ y1l $(\bar{X}=45.43), \quad$ ve $11-15$ y1l $(\bar{X}=46.37)$ eczacılık yapanlara göre zamanlarını daha iyi planladıkları belirlenmiştir.

Eczacıların uygulama boyutuna ilişkin zaman yönetimi davranışları arasında eczacılık yapma sürelerine göre anlamlı fark bulunmamıştır.

Araştırmaya katılan eczacıların zaman yönetimi davranışları açısından eczacılık yapma sürelerine göre toplamda da anlamlı farklılık gösterdiği görülmektedir, $F(4.208)=5.17, \mathrm{p}<.05$. Gruplar arasında yapılan çoklu karşılaştırmada 21 yıl ve daha fazla eczacılık yapanların ( $\bar{X}=85.27)$ diğerlerine göre zamanlarını daha iyi planladıkları belirlenmiştir.

\section{SONUÇ VE TARTIŞMA}

Zaman Yönetimi Davranış Anketine katılan eczacıların, \%38'i 25-34, \%35.7'si 35-44, \%22.1'i 45-54, \%4.2'si ise 55-64 yaşları arasında, \%63.4'ünü bayan, \%36.6'sını ise erkektir, \%29.6's1 1-5 y11, \%22.5'i 6-10 y11, \%16.4'ü 11-15 yı1, \%14.1'i 16-20 yı1, \%8,9'u 21-25 y11, \%8.5'i ise 25 y1ldan uzun süredir eczacilık yapmaktadırlar.

Ankete katılan eczacıların, \%3.8'i her zaman, \%8.9'u çok sık, \%28.2'si oldukça sık, \%34.7'si ara sıra, zamanlarını kimlere ve nereye harcadıklarının analizini yaptıklarını, \%2.9'u hiçbir zaman, zamanlarını kimlere ve nereye harcadıklarının analizini yapmadıklarını belirtmişlerdir. Eczacıların çoğunluğu zamanlarını kimlere ve nereye harcadıklarının analizini çok titiz yapmamaktadır. Oysa, günlük veya haftalık olarak zamanın kimlere ve nereye harcandığının analizinin yapılması, boşa geçirilen zamanın ve gereksiz görüşmelerin saptanması ve bu konuda önlem alınarak zamanın etkin ve verimli kullanılması için son derece önemli bir unsurdur.

Ankete katılan eczacıların, \%16'sı her zaman, \%23'ü çok sık, \%5.6'sı oldukça sık, \%31.9'u ara sıra, işleriyle ilgili bir yıllık veya daha uzun süreli amaçlar belirlediklerini, \%23.5' $\mathrm{i}$ ise hiçbir zaman işleriyle ilgili bir yıllık veya daha uzun süreli amaçlar belirlemediklerini belirtmişlerdir. Eczacılar, uzun süreli amaçlar belirlerken çekingen davranmaktadırlar. Bunun nedeni ise, ülke ekonomisinde ve ilaç piyasasında meydana gelen değişimlerin çok sık olması ve eczacıların da çok fazla risk almak istememeleri olabilir.

Eczaciların, \%16.9'u her zaman, \%16'sı çok sık, \%16's1 oldukça sık, \%35.2'si ara sıra, günlük veya haftalık yaptıkları programları değerlendirdiklerini, \%15.5'i hiçbir zaman günlük veya haftalık yaptıkları programları değerlendirmediklerini belirtmişlerdir. Günlük veya haftalık yapılan programların değerlendirilmesi, yapılan işlere harcanan zamanın belirlenmesi, günlük veya haftalık hedeflere ne ölçüde ulaşıldığının görülmesi için gereklidir. Eczacılar, işleri için ayırdıkları zamanı 
nasıl kullandıklarına bakarak günlük ve haftalık verimliliklerini hesaplamalıdırlar. Daha iyi zaman planlaması için, koydukları hedefleri göz önüne alarak verimli, verimsiz oldukları günleri ve zamanları belirlemeli ve verimliliklerini arttırmak için yeni yöntem ve stratejiler geliştirerek uygulamaya koymalıdırlar (3).

Ankete katılan eczacıların, \%4.2'si her zaman, \%6.1'i çok sık, \%16'sı oldukça sık, \%31.9'u ara sıra, beklenmedik ve acil durumlar için ek zaman ayırdıklarını, \%41.8'i hiçbir zaman beklenmedik ve acil durumlar için ek zaman ayırmadıklarını belirtmişlerdir. Her yönetici gibi eczacıların da beklenmedik ve acil durumlarla karşılaştıklarında zaman sıkıntısı yaşamamaları için, yapmaları gereken işleri planlamaları, bu plan doğrultusunda hareket ederek, zaman kazanmaları ve bu gibi durumlar için ek zaman ayırabilmeleri gerekmektedir.

Ankete katılan eczacıların, \%25.4' ü her zaman, \%45.5'i çok sık, \%16.9'u oldukça sık, \%10.8'i ara sıra, bir işe başladıktan sonra işi bitirene kadar 1srar ettiklerini belirtmişlerdir. Bir işe başladıktan sonra işi bitirene kadar ısrar etmediğini belirten eczacı olmamıştır. Bir işe başladıktan sonra bitirene kadar ısrar etmek, bir işi bitirmeden başka bir işe başlamayı önleyen en temel önlemdir. Bir işi bitirmeden diğerine başlayan eczacılar, üzerinde çalıştıkları işe tam olarak yoğunlaşamazlar, dolayısıyla da o işi tam anlamıla yapamaz, işlerinde etkin ve verimli çalışamazlar ve en önemlisi zaman kaybederler. Bu nedenle de, ilk önce, başladıkları işi tamamen bitirmeli ve daha sonra diğer işe geçmelidirler.

Ankete katılan eczacıların, \%5.6' s1 her zaman, \%9.9'u çok sık, \%17.4'ü oldukça sık, \%20.7'si ara sıra, işlerinin kesilmesini önlemek için önlem aldıklarını, \%39'u hiçbir zaman işlerinin kesilmesini önlemek için önlem alamadıklarını belirtmişlerdir. Eczacılar, işlerinin kesilmesini önlemek için, beklenmeyen ziyaretçilere, tıbbi mümessillere bazen kibarca meşgul olduklarını izah ederek işlerine yönelmekte, bazen de bu görüşmeleri yapmak için personellerine yetki devrinde bulunmaktadırlar. Almaları gereken bir diğer önlem de, başkalarının işlerini yapmayı reddetmektir. Eczacıların bunları her zaman yapamama nedenleri, "hayır" diyememeleri, kendilerine güvenerek sağlıklarını emanet eden hastalarını kırmaktan çekinmeleridir. Eczacılar, "hayır" deme hakları olduğunu bilmeli, beklenmeyen ziyaretçileri ve başkalarının işlerini yapmayı kibarca fakat net bir şekilde reddedebilmeli ve kendi işlerine yararı olmayan görüşmelere ve başkalarının işlerine harcayacakları zamanı kendi işlerine harcamalıdırlar (7).

Ankete katılan eczacıların, \%15'i her zaman, \%3,3'ü çok sık, \%11,3'ü oldukça sık, \%33,8'i ara sıra, işlerine yararı olmayacak görüşmeleri reddedebildiklerini, \%35,7'si hiçbir zaman işlerine yararı olmayacak görüşmeleri reddedemediklerini belirtmişlerdir. Eczacıların çoğu, işlerine yararı 
olmayacak görüşmeleri reddedememektedirler. Böylece, kendileri ve işleri için öncelikli olan görevlerini yerine getirirlerken işlerinin kesilmesine neden olmaktadırlar.

Ankete katılan eczacıların, \%47.9' u her zaman, \%31'i çok sık, \%13.6'sı oldukça sık, \%6.6'sı ara sıra, yapılan işlerde mükemmellik aradıklarını belirtmişlerdir. Yapılan işlerde hiçbir zaman mükemmellik aramadığını belirten eczacı olmamıştır. Eczacılar, sağlık sektöründe hizmet verdiklerinden ve insan sağlı̆̆ her şeyin üzerinde olduğundan, işlerin doğru bir biçimde yapılmasını beklerler. Eğitimli ve deneyimli personel tercihlerinin bir nedeni de budur. Ancak hayatın her dalında ve tüm mesleklerde olduğu gibi, eczacılıkta da mükemmellik arayışının çok yüksek düzeyde olması, eczacıların hayal kırıklığına uğramalarına ya da sağlık sorunları yaşamalarına neden olabilir.

Ankete katılan eczacıların, \%47.9'u her zaman, \%31'i çok sı, \%13.6'sı oldukça s1k, \%6.6's1 ara sıra, yapılan işlerde mükemmellik aradıklarını belirtmişlerdir. Yapılan işlerde hiçbir zaman mükemmellik aramadığını belirten eczacı olmamıştır. Eczacılar, sağlık sektöründe hizmet verdiklerinden ve insan sağlığı her şeyin üzerinde olduğundan, işlerin doğru bir biçimde yapılmasını beklerler.

Ankete katılan eczacıların, \%1.4' ü her zaman, \%7.5'i çok sık, \%8'i oldukça sık, \%32.4'ü ara sıra, beklemedikleri ziyaretçiler için belirli kabul saatleri ayarladıklarını, \%49.3'ü hiçbir zaman beklemedikleri ziyaretçiler için belirli kabul saatleri ayarlamadıklarını belirtmişlerdir. Özellikle semt eczanelerinde çok fazla beklenmeyen ziyaretçi olmaktadır, bu ziyaretçiler de aynı semtte oturan, ilaç ihtiyaçlarını sürekli olarak o eczaneden karşılayan hastalardır. Dolayısıyla da, eczacılar, bu kişilerle sürekli diyalog içinde olduklarından ve hastalarını kırmak istememeleri nedeniyle onları reddedememektedirler. Ancak, çok meşgul oldukları zamanlarda, kendilerinden kibarca özür dileyerek, işlerine devam edebilmekte ya da dışarıda yapmaları gereken önemli işleri olduğunda durumu izah ederek eczaneden dışarı çıkmaktadırlar. Semt eczaneleri dışındaki eczanelerde ise, beklenmeyen ziyaretçilerin başında tıbbi mümessiller gelmektedir. $\mathrm{Bu}$ durumda, eczacılar personele yetki devrinde bulunmakta ve eczacı kendi işleriyle ilgilenirken personel mümessillerle görüşmektedir. Zamanın bir bölümü bir kenarda saklanmalıdır. Hiç umulmadık firsatlar ve sorunlar yaşamın tuzu biberidir. Akıllı bir yönetici planlama yaparken tüm olumlu ve olumsuz ihtimalleri göz önünde tutmalıdır (8). Zamanın kontrolünü elde tutmak için, olması muhtemel aksaklıklara karşı hazırlıklı olmalı, mümkünse bunları önceden önlemeye çalışmalı, yine de meydana gelirlerse, önceden hazırlanan acil müdahale planı devreye sokulmalıdır (7). Dolayısıyla da eczacılar, beklemedikleri durumlar için zaman ayırmalı ve beklenmedik ziyaretçiler için de belirli kabul saatleri ayarlamalıdır. 
Ankete katılan eczacıların, \%15.5'i her zaman, \%30'u çok sık, \%24,.'ü oldukça sık, \%23.5'i ara sıra, yapılacak işleri için son bitim tarihi belirlediklerini, \%6.1'i hiçbir zaman yapılacak işleri için son bitim tarihi belirlemediklerini belirtmişlerdir. Son bitim tarihi belirlemek, planlamanın en net örneklerinden biridir ve işlerin birikmesini önlemek için alınması gereken önlemlerin başında gelmektedir. Eczacılar çoğunlukla, işleri için son bitim tarihi belirlemektedirler.

Ankete katılan eczacıların, \%2.3'ü her zaman, \%15.5'i çok sık, \%27.2'si oldukça sık, \%38'i ara sıra, yapmaları gereken işleri önemli olmayan nedenlerle ertelediklerini, \%16.9'u hiçbir zaman yapmaları gereken işleri önemli olmayan nedenlerle ertelemediklerini belirtmişlerdir. Yapılması gereken işlerin ertelenmesi, en yaygın zaman sorunlarından biridir. Bugünün işinin yarına ertelenmesi, yarının iş yükünü arttırmaktır. Erteleme işlerden bir kaçış yolu değildir, çünkü, ertelenmiş bir iş yapılmak üzere bekleyen ve eninde sonunda yapılacak olan iştir. Eczacıların genellikle, yapmaları gereken işleri önemli olmayan nedenlerle erteledikleri gözlenmiştir. Bu, eczacılar için çok büyük bir problemdir, çünkü, zaten yoğun olan iş tempoları, ertelenmiş olan işlerin de eklenmesiyle daha da yoğun bir hale gelmekte, eczacılar işlerini yetiştirememektedir.

Ankete katılan eczacıların, \%10.8'i her zaman, \%20.2'si çok sık, \%27.7'si oldukça sık, \%39.4'ü ara sıra, yapılacak işlerin listesini hazırladıklarını, \%1.9'u ise hiçbir zaman liste yapmadıklarını belirtmişlerdir. Yapılacaklar listesi, planlama sistemleri arasında en kullanışlı olanıdır. Eczacılar, kısa süreli planlar yapabilmek için, her sabah veya her akşam yapılacaklar listesi hazırlamalıdırlar. Çünkü bu planlama sistemi, eczacıların amaçlarına ulaşmasını sağlayacak, onlara zaman kazandıracak ve işlerini zamanında yetiştirmelerine yardımcı olacaktır (7)

Ankete katılan eczacıların, \%8.5'i her zaman, \%3.3'ü çok s1k, \%14.1'i oldukça sık, \%44.6's1 ara sıra, eczanede çalışan personellerinin kendilerine sorunlarını anlatabilmeleri için günün veya haftanın belirli bir bölümünü ayırdıklarını, \%16'sı hiçbir zaman ayırmadıklarını belirtmişlerdir. Eczacıların çok büyük bir kısmı, personellerine sorunlarını anlatabilmeleri için zaman ayırmaktadırlar. Eczacılar, personellerinin etkin ve verimli çalışabilmelerini sağlamak için, belirli zamanlarda personellerinin sorunlarını dinlemeli, birlikte çözüm yolları aramalı ve bu çözüm yollarını uygulamaya koymalıdırlar. Böylece, personel huzurlu, etkin ve verimli çalışacaktır, bu da dolaylı olarak eczacının verimini ve etkinliğini arttıracaktır.

Ankete katılan eczacıların, \%16.9'u her zaman, \%31.9'u çok sık, \%34.7'si oldukça sık, $\% 15$ 'i ara sıra, işlerini belirli bir programa göre yaptıklarını, \%1.4'ü ise işlerini hiçbir zaman belirli bir programa göre yapmadıklarını belirtmişlerdir. Eczacılar işlerini belirli bir programa göre 
yapmalıdırlar, böylece daha verimli çalışılır ve zaman kazanırlar, dolayısıyla da işlerini yetiştirememe stresi yaşamazlar.

Ankete katılan eczacıların, \%18.8'i her zaman, \%27.7'si çok sık, \%38.5'i oldukça sık, \%12.7'si ara sıra, yapılacak işleri öncelik ve önem sırasına göre dizdiklerini, \%1.4'ü hiçbir zaman yapılacak işleri öncelik ve önem sırasına göre dizmediklerini belirtmişlerdir. Eczacıların sahip olduğu zaman, çoğunlukla, tüm işlerini yapmaları için yeterli olmaz ve işlerini zamanında yetiştirememe stresi yaşamaktadırlar. Bu nedenle, işleri öncelik ve önem sırasına göre listelemeli, en önemli ve en önce yapılması gereken işleri ilk önce yapmalı, listede gereksiz işler varsa bunları yapmamalı ya da yapılması gerekiyorsa personele devretmelidirler.

Ankete katılan eczacıların, \%19.7'si her zaman, \%20.7'si çok sık, \%41.3'ü oldukça sık, \%16.9'u ara sıra, işlerini planlamak için zaman ayırdıklarını, \%1.4'ü ise işlerini planlamak için hiç zaman ayırmadıklarını belirtmişlerdir. Planlama, zaman yönetiminin en önemli unsurlarından biridir. Eczacılar, ne kadar zamanda, nasıl ve ne zaman işlerini yapacaklarını bilirlerse, amaçlarına daha kolay ulaşır, daha etkin ve verimli çalışır dolayısyla zaman kazanırlar.

Ankete katılan eczacıların, \%9.4'ü her zaman, \%40.8'i çok sık, \%23'ü oldukça sık, \%18.8'i ara sıra, işlerini son anda yetiştirme durumunu yaşadıklarını, \%7'si hiçbir zaman işlerini son anda yetiştirme durumunu yaşamadıklarını belirtmişlerdir. Eczacıların hemen hemen yarısı işlerini son anda yetiştirememe durumu yaşadıkları, zamanlarını iyi yönetemedikleri gözlenmiştir.

Ankete katılan eczacıların, \%34.3'ü her zaman, \%45.5'i çok sık, \%12.2'si oldukça sık, \%5.6'sı arasıra, randevu ve görüşme saatlerine uyduklarını, \%1.4'ü hiçbir zaman randevu ve görüşme saatlerine uyamadıklarını belirtmişlerdir. Eczacılar, randevu ve görüşme saatlerine uymakta, ellerinden geldiğince gecikmemeye çalışmaktadırlar. Bunun için de, önceden belirlenen randevu ve görüşmelerini, günlük veya haftalık planlarına dahil edip unutmayarak, zamanında hazır bulunmaktadırlar. Böylelikle hem kendi zamanlarını doğru yönetmekte hem de karşılarındaki kişiyi bekletmeyerek en önemli nezaket kuralına uymakta, onların da zamanlarını çalmamaktadırlar.

Ankete katılan eczacıların, \%64.8'i her zaman, \%21.1'i çok sık, \%7.5'i oldukça sık, \%2.8'i arasıra, her şeyin yerli yerinde olduğu ve kolayca bulunabileceği bir dosyalama sistemine önem verdiklerini, \%1.9'u hiçbir zaman her şeyin yerli yerinde olduğu ve kolayca bulunabileceği bir dosyalama sistemine önem vermediklerini belirtmişlerdir.

Ankete katılan eczacıların, \%1.4'ü her zaman, \%4.2'si çok sık, \%6.6'sı oldukça sık, $\% 28.2$ 'si ara sıra, eve iş götürdüklerini, \%59.2'si hiçbir zaman eve iş götürmediklerini 
belirtmişlerdir. Eczacıların yarısı eve çok sık olmasa da iş götürmektedirler. Bu da, yeterince yetki devrinde bulunmadıklarını ve çoğu zaman da zaman tuzaklarına yenik düştüklerini ve işlerini zamanında yetiştiremediklerini göstermektedir.

Ankete katılan eczacıların, \%57.3' ü her zaman, \%24.9'u çok sık, \%11.3'ü oldukça sık, \%5.2'si ara sıra, eczaneleriyle ilgili evrak ve faturaları zamanında kontrol edip düzenlediklerini, \%0. 9'u hiçbir zaman eczaneleriyle ilgili evrak ve faturaları zamanında kontrol edip düzenleyemediklerini belirtmişlerdir. Eczacılar, ilaç depolarından ilaç temin ettikleri ve bu ilaçları hastalarla buluşturdukları için sürekli olarak faturalarla, reçetelerle, ilaç küpürleriyle uğraşmak zorundadırlar. Eczacıya ilaç depolarının kestiği faturalar ve ayrıca elektrik, su, telefon faturaları zamanında ödenmelidir. Bunun yanında, ilaç küpürleri ve reçeteler de kurumlara zamanında iletilmelidir. Bu evrakların düzenli bir şekilde takip edilebilmesi, her şeyin yerli yerinde olduğu ve kolayca bulunabileceği düzenli bir dosyalama sistemine bağlıdır. Eczacı, evraklarını dosyalara, tarih sıralamasına göre yerleştirmeli ve her gün bu evrakları kontrol etmelidir. Ayrıca ödeme günlerini ayrı bir yere not etmelidir. Böylece fatura günlerini kaçırmaz, ödemeler için hazırlıklı olur, reçete ve küpürleri de zamanında kurumlara iletebilirler. Bunun yanında, düzenli bir dosyalama sistemine sahip oldukları için de, gerekli evrakları arayıp bulmak için zaman kaybetmekten kurtulurlar.

Ankete katılan eczacıların, \%1,4'ü her zaman, \%5,6'sı çok sık, \%23,5'i oldukça s1k, \%44,1'i ara sıra, bir işten diğerine plansız ve amaçsız geçme eğiliminde olduklarını, \%24,9'u hiçbir zaman bir işten diğerine plansız ve amaçsız geçme eğiliminde olmadıklarını belirtmişlerdir. Eczacıların, bir işten diğerine plansız ve amaçsız geçme eğiliminde oldukları gözlenmiştir. Bu eğilim, önemli zaman tuzaklarından biridir. Bu nedenle, eczacılar, kendilerine kısa veya uzun süreli amaçlar belirlemeli; günlük veya haftalık olmak üzere, yapılması gereken işlerin bir listesini hazırlamalı ve bu işleri de öncelik ve önem sırasına göre dizmeli, belirlemiş oldukları amaçlar ve bu doğrultuda yaptıkları planlar ışığında ilerlemelidirler.

Ankete katılan eczacıların, \%5.2'si her zaman, \%16.4'ü çok sık, \%33.3'ü oldukça sık, \%39'u ara sıra, özel ricalarla veya kendi istekleriyle başkalarının işlerini yaptıklarını, \%4.7'si hiçbir zaman yapmadıklarını belirtmişlerdir.

Ankete katılan eczacıların, \%14.1'i her zaman, \%25.4'ü çok sık, \%27.2'si oldukça sık, \%32.4'ü arasıra, özel telefon görüşmeleri yaptıklarını belirtmişlerdir. Özel telefon görüşmeleri yapmadığını belirten eczacı olmamıştır. Özellikle bayan eczacıların erkek eczacılara oranla, zamanlarının daha büyük bir kısmını telefon başında özel görüşmeler yaparak geçirdikleri 
saptanmıştır. Bunun temel nedeni ise, bayan eczacıların eczacı olarak sahip oldukları sorumlulukların yanı sıra, bir de ev hanımı ve anne olarak sorumluluklara sahip olmalarıdır.

Ankete katılan eczacıların, \%4.7'si her zaman, \%12.7'si çok sık, \%22.5'i oldukça sık, \%47.9'u arasıra, masalarının üzerinde halen çalıştıkları konu ile ilgisi olmayan şeylerin bulunduğunu, \%11.3’ü hiçbir zaman bulunmadığını belirtmişlerdir. Eczacılar, masaları üzerinde sadece, işlerine yarayan, halen üzerinde çalıştıkları konu ile ilgisi olan fatura, ilaç broşürü, evrak, kitap ve araçları bulundurmalıdırlar. Çünkü, kağıt yığını büyüdükçe, en altlarda nelerin olduğu unutulur ve çoğu zaman aranılan bir evrakın bulunması için kağıtlar karıştırılmaya başlanır, bu da hem masanın daha çok karışmasına hem de zaman kaybına neden olur. Bunu önlemek için eczacılar, çalıştıkları konu ile ilgisi olmayan yada işi bitmiş olan evrak, ilaç küpürü, fatura ve araç gereci yerlerine kaldırmalı, personelin kendilerine sormadan masaları üzerine ellerine geçen her kağıdı bırakmasını önlemeli ve personeli belirli sürelerde eczacı masasını temizlemek için görevlendirmelidir (7).

Katılımcıların zaman yönetimi davranışları genel olarak incelendiğinde ise bu davranışların cinsiyete göre anlamlı farklılık gösterdiği, erkeklerin, kadınlara göre zamanlarını daha iyi yönettikleri bulunmuştur. Bu durumun nedeni kadınların eczacı kimliği yanında ev hanımı ve anne kimliği nedeniyle zaman yönetimini akılıı yapamadıkları olarak düşünülebilir.

Araştırmaya katılan eczacıların zaman yönetimi davranışları arasında yaşa göre toplamda da anlamlı farklılık gösterdiği bulunmuştur. Gruplar arasında yapılan çoklu karşılaştırmada, 45 ve daha üzeri yaşa sahip olanların 25-34 yaşta olanlara göre zamanlarını genel olarak etkili kullandıkları görülmüştür. Bunun nedeni ise insanların belli yaştan sonra pek çok maddi, manevi sorunlarını çözebilmiş artık işinde iyice ustalaşmış, temel fizyolojik ve güvenlik gereksinimlerinin önemi azalmış; başarı, saygınlık gibi gereksinimleri ön plana çıkması olabilir. Birey, bir taraftan mevcut konumunu korumaya çalışırken diğer taraftan eczanemde daha ne kadar verimli olabilirim olanaklarını araştırabilir (9).

\section{ÖNERILER}

$\mathrm{Bu}$ çalışmanın sonuçlarına göre, eczane eczacılarına eczanelerinde çalışan personele rutin ve kolay işlerde yetki devrini arttırmaları ve yine personele eğitimin sürekli olması gerektiği, beklenmeyen konukların eczaneye gelmesinin engellenmeye çalışılması, özel telefon görüşmelerinin işlerin daha az yoğun olduğu zamanlarda veya akşam saatlerinde yapılması, özellikle hasta yoğunluğu fazla olan eczanelerde 2. ya da 3. eczacı çalıştırarak hastalarla iletişimin 
arttırılması önerilebilir. Çünkü eczane eczacılı̆̆ı, kaliteli bir sağlk sistemi zincirinde çok önemli bir halkadır.

Bunun yanında, Türkiye'de eczane eczacılığının mesai saatleri (sabah 08:00-akşam 19:00) yeniden düzenlenebilir. Mesai saatleri kısaltılıp, nöbetçi eczaneler arttırılabilir. Ayrıca iyi eczacılık uygulamaları gereği, daha kaliteli eczacılık hizmeti için meslek örgütlerinin zaman yönetimi konusunda eğitimlere ağırlık vermesi önerilebilir.

\section{KAYNAKLAR}

1. Akat, İ., Budak, G., Budak, G., İşletme Yönetimi, Fakülteler Kitapevi, İzmir, (1999).

2. Türkçe Sözlük, Türk Dil Kurumu Yayını, Sayı: 403, 6. Baskı, Ankara, (1981).

3. Karabulut, S., Yönetimde 3 Boyut: Zaman-Toplantı-Stres Yönetimi, AKM Yayınları, İstanbul, (1996).

4. Mackenzıe, R. Alec, Zaman Tuzağı, (Çev: Y. Güneri), İlgi Yayıncılık, Modern Yönetim Dizisi, İstanbul, (1989).

5. Akalın,K., İlaç ve Eczacılık Uluslar arası Anlaşmalar, Kanunlar, Yönetmelikler, Genelgeler, Ankara, (1996).

6. Sümbüloğlu, K., Sümbüloğlu, V., Biyoistatistik, 6. Baskı, Özdemir Yayıncılık, Ankara, (1987).

7. Smith, J. , Daha İyi Nası1... Zaman Yönetimi, How to be a Better...Time Manager, (Çev: Ali Çimen), Timas Yayınları; 446, Başarı Dizisi; 17, İstanbul, (1998).

8. Adair,J., Adair,T., Zaman Yönetimi, (Çev: B.Güngör), Öteki Yayınevi, Ankara, (1993).

9. http://www.insanbul.net/kitap/kisim2.htm (Erişim Tarihi: 12.8.2005)

Received: 14.07.2005

Accepted: 18.1012005 